\title{
Internet Memes : Representation of Indonesian Political Culture in Jakarta Gubernatorial Election 2017
}

\author{
Rahmi Surya Dewi \\ Doctoral Student Faculty of Communication Sciences \\ University of Padjadjaran \\ Bandung-Indonesia \\ rahmi.ikom@gmail.com
}

\author{
Aceng Abdulllah \\ Faculty of Communication Sciences \\ University of Padjadjaran \\ Bandung-Indonesia
}

\author{
Eni Maryani \\ Faculty of Communication Sciences \\ University of Padjadjaran \\ Bandung-Indonesia \\ emaryani@gmail.com
}

\author{
Dadang Suganda \\ Faculty of Humanities \\ University of Padjadjaran \\ Bandung-Indonesia
}

\begin{abstract}
Jakarta Gubernatorial Election 2017 may receive considerably significant attention from Indonesian society. Many assume it resembled the presidential election because of the 'political heat' of the moment. This is apparent in particular conversations in social media, and even seen as the message of manipulation sign appeared as Instagram memes with the three candidates for the governor. This study aims to reveal the form of political culture which developed during the Jakarta Gubernatorial Election in Indonesia in 2017. Researcher felt the urge to analyze the symbols of internet memes in Instagram, especially with the \#pilgubdki hashtag as one effort to win the election. This study uses the qualitative method with semiotic analysis from Roland Barthes with researcher opted to conduct the documentation, observation, and literature study as data collection techniques. This study found some types of memes circulated on the Instagram with the combination of texts and photos. It is clear that the political culture of memes shows "subtle" imagery through debates and political campaigns by political elites. However, the evidence shows that negative imagery, religious view, and racial issues emerged and made the twisted story and evolved as the criticism in Indonesian society.
\end{abstract}

\section{Keywords: internet memes; political culture; Jakarta gubernatorial election}

\section{INTRODUCTION}

Jakarta Gubernatorial Election 2017 may receive considerably huge attention from Indonesian society. The condition has brought tremendous change in the political culture in Indonesia. It is reflected in the community acted as the winning team or the supporter of the candidates. Thanks to the development of information technology and media, this behavioral phenomenon is reflected in the daily use of social media. One of many forms of this communication behavior is reflected through " Internet Memes." This meme appeared rampantly on Instagram throughout the Jakarta Gubernatorial Election campaign and increased significantly in the silent period and when entering the second round of elections.

Instagram has a massive use in Indonesia because its users increase from year to year. Based on APJII (Asosiasi Penyelenggara jaringan Internet Indonesia $=$ Association of Indonesian Internet Network Providers) research, as reported by tekno.kompas.com and palembang.tribunnews.com, during the year of 2016, from 265.2 million Indonesians, 132.7 million people are connected to the internet. Instagram itself, on the other hand, is ranked as the third biggest clicked social media in the world. On the campaign trail in 2017, Instagram is used to as the medium to post the memes about the candidates. The meme is not only used to spread humor in social media but also contains political messages that impacted social groups instead. Shifman[1] stated that "Memes may best be understood as pieces of cultural information that pass along from person to person, but gradually scale into a shared social phenomenon. Although they spread on a micro basis, their impact is on the macro level: memes shape the mindsets, forms of behavior, and actions of social groups." Some people perceive this common situation as the reflection and criticism in society. However, the core problem is that political culture in Indonesia has entered into political imagery battle and political attack. It should have been known that campaign trail should emphasize the candidates' competency to solve the issues on society, uphold justice, lift prosperity, and establish harmony in all levels of society.

Those competencies have long disappeared in Indonesia. The candidates often perceived as the figure who can bring 'benefits' for some people. Unwittingly, the winning teams join the campaign trail and form particular images of the candidates. That activist/winning team unconsciously promotes the unhealthy form of a political campaign which leads to blasphemous against the opponents and abundant

Corresponding authors: Rahmi Surya Dewi 
exposed of political image. This condition is exacerbated by the lack awareness of political discourse and the importance of electing a competent leader. Additionally, some Indonesian are in 'unconsciousness' of symbolic consumerism and hedonism. Those new symbols emerge in the globalization era. These symbols appear in Internet memes related to Jakarta Gubernatorial election. Hence, it is pivotal to analyze the symbols and meaning of memes which on Instagram during the election campaign.

\section{A. Progress of the meme concept}

The term meme was popularized by Richard Dawkins in his book The Selfish Gene in 1976 to define the birth of a culture with the assumption that culture is the formation of many replicators[2]. This concept has drawn debate among academics over the years. However, lately, the concept of this meme has become an integral part of Internet user's language. Memes now present in the public sphere, not as sporadic entities, but also as a vast collection of text and images[3]. The concept of memes has expanded along with the use of computers and the exponential growth of the internet, particularly in internet forums, conversations, blogs, and social networks; the concept was created as a new form of Internet communication[4]. Shifman said that internet memes could be perceived as a modern "folktale" which built along with norms and values through cultural artifacts such as photo shopped images or urban legends [5]. The idea of memes has mutated and evolved in a new direction by hijacking the original idea through one's creativity before it disseminates. Memes are ideas, styles, or actions that widely spread through the internet in the form of mimicry [6].

Meme as an Internet culture portrays a way in which ideas are imitated, disseminated, and mediated from people to through interaction or conversation. Meme as an operational unit of cultural transmission can improve the understanding of the cultural change processes. Albeit memes can be understood as cultural units, other cultural units cannot be transmitted through duplication [7]. Internet memes formed in the combinations of images, photos, slides, and texts intended to respond to an issue in social discourse. Memes cannot only be viewed as creative-technical activities but seen as creativesubstantive meanings, deliberately constructed and highlighted meanings, such as politically-charged memes[8]. Internet memes are often highlighted along with another hype topics or issues in the community and discussed by Internet users in the comment section on social media. Grundlingh [9] suggested in his article that Meme is also considered as a speech act by internet users. When memes are created using special semiotics, internet user subsequently interprets them to receive the message from the meme maker. Memes can be re-created for different purposes and can speculate on how they may fit into speech actions at different times[9].

When the interaction begins on social media, meme always portrayed with a variety of messages, not to mention the political content revolves around Jakarta Gubernatorial Election. The meme is not only a form of humor; it often conveys elements of defamation, satire, criticism, and even 'mock' against the candidates, politicians, governments, and anyone made as the object of an Internet meme. Here's an example of a photo being manipulated into a meme;

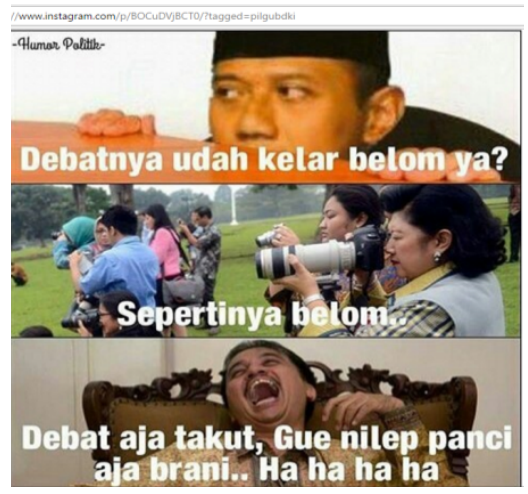

Source: Instagram \#pilgubdki

\section{B. Political Culture}

Political Culture is a collection of symbols and meanings or form of actions that control the making process of political claims and the formation of opinions, either individually or collectively. Culture, which is meant as a symbol pattern, meaning, and form of joint action that allows and confine words and behavior of people [10]. Political culture impacted the implementation of the political system. Gabriel A. Almond defines political culture as a typical citizen-oriented attitude toward the political system and its various parts, and attitudes to the role of citizens within the system. Political culture can be classified into three parts; Parochial Political Culture, Subject Political Culture; and Participant Political Culture [11]. Although the approach of political culture is often used in highlighting issues of hegemony and power, it is not always referred to concepts or literature approaches until historians give meaning to "political culture" [12]. To exemplifies, political culture also prioritizes the psychological dimension of political systems such as attitudes, the system of beliefs, and symbols possessed by individuals and embedded within society [13].

Based on those three classifications of political culture mentioned, the type which related to this study is the third one, the political culture of the participants. Internet users in this regard are presumed as individuals who are active in producing, commenting, and disseminating political memes (related to Jakarta Head Election 2017) in social media. Society, in this regard, is an individual who is consciously 
making, criticizing, and spreading the meme on social media. On the other, other community groups may embrace the parochial type and subject political culture as well.

\section{RESEARCH METHOD}

This study uses a qualitative approach with critical paradigm and semiotics method of Roland Barthes analysis model which aims to capture subjective meanings, definitions, and symbols lied behind the communication behavior that appears in Instagram memes. This method is intended to reveal the meaning and dismantle the ideology behind the text/images memes revolve in Instagram with the \#pilgubdki hashtag around Jakarta Gubernatorial Election 2017. Critical paradigm enables researchers to study and review the photo objects either in the remix or mimicry formed combined with writings. Besides, critical paradigm also provides the opportunity to interpret social phenomenon that can shape the audience's views such as meme notion that occurred in social media around Jakarta Gubernatorial Election round. Memes analyzed are those appeared in the silent period of the election, for instance; two days before the election (13 and 14 February 2017) and those who go viral on Instagram.

\section{RESULT AND DISSCUSSION}

The presence of social media has become an alternative channel of public information. The concept of many to many has made everyone a "journalist" who can disseminate information with respective versions. The current use of the internet is quite useful to generate public awareness of political issues, despite there is no evidence in this case with the relationship between Internet-used and the voting participation rates. There has been a particular attention to the internet meme on politics since the Presidential Election in Indonesia in 2014. These political memes were once again rampant during the 2017 Jakarta Gubernatorial Election. The memes were analyzed by the semiology of Barthes. Barthes himself delivered his ideas in a book called mythologies, which contains a collection of short essays in various examples of popular culture. Barthes asserts that semiology offered a 'dyadic' or two-part model of the sign, signifier and signified as composed by Saussure. There is also the third term, the sign itself (linguistic and mythological) which contains the signifier and the signified [14] is the type of speech act. Myth cannot serve as an object, concept or idea; myth is the way to interpret a form. The myth is a communication system in a message form, which cannot be restricted only to oral speech. Messages may consist of writing styles or representations; not only in the form of written discourse but also in the form of photography, cinema, coverage, sports, performances, publications in all of which can serve as 'supporters of mythical speech' [15]. In Jakarta Gubernatorial Election 2017, this mythical circulation is widely spread in the form of internet memes in Instagram. Here are some examples of Internet memes that counts the element of 'SARA (Ethnic, Religion, Race, and Intergroup Relations), mazy 'facts, and the sign that fuses with reality.

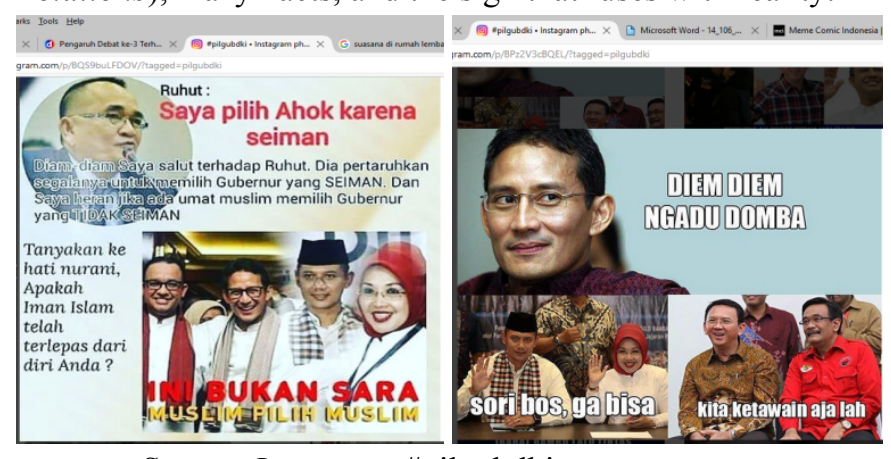

Source: Instagram \#pilgubdki

A. The analysis of meme; "Jakarta Bakal Nge-fly"("Jakarta Will Get High")

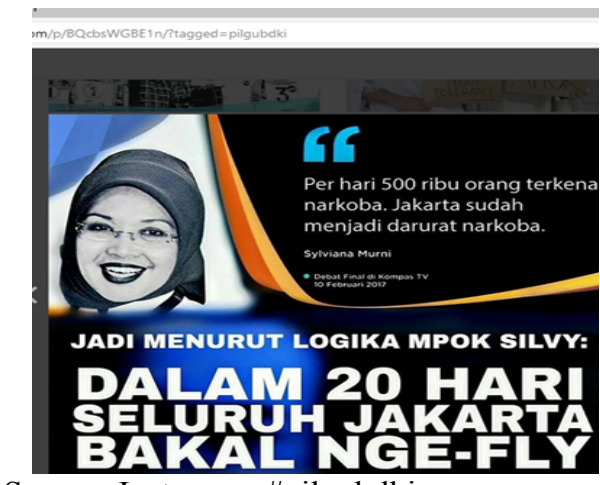

Source: Instagram \#pilgubdki

This meme appeared on February 13, 2017, in the \#pilgubdki hashtag. The meme of Sylviana Murni, the vice governor candidate who paired with Agus Yudhoyono, was placed on this candidate campaign background. The image was an edited picture when Sylvi and Agus were on the final debate campaign aired on Kompas TV. There are three major signifiers in this meme. The first signifier is Silvy's big smile on a 'bright' face. At the first level of the Barthes's semiology, the above signifier can be interpreted as a sign of joy and optimism in conveying the message. Secondly, a quote of "500 thousand people are exposed to drugs every day. Jakarta is entering the narcotics emergency!" (narkoba = narcotics and drugs). The second signifier is that Sylvi wants to convince the audience that Jakarta has entering the drugs emergency which will be tackled this candidate so that they can diminish the number of drug users in Jakarta. The third signifier is written in a larger font, "According to Mpok Sylvi: In 20 Days, Jakarta Will Get High." In the third signifier, it can be concluded that Jakarta residents with 10,000 people 
approximately will get high 20 days from now (nge-fly= to achieve a state of mental euphoria, as from substance intoxication). It is clear that the creator of this meme is deliberately adding the text to question Sylvi's use of logic when delivering the message.

The overall sign of "Jakarta Will Get High" is the weakness of Sylvi regarding the data analysis that she gets regarding the threat and rampant drug disseminations in Jakarta. The creator of this meme deliberately highlighted this weakness with the purpose to shape audience's mind in voting decisions. This meme was disseminated on purpose during the silent period, precisely two days before the election took place. By the regulations and the ethics of the campaign, there should not be any campaigning form in the silent periods, even to impose the defamation to a particular candidate.

\section{B. The Analysis of meme; "Kaya makin Kaya"(= "The Rich is} Getting Richer")

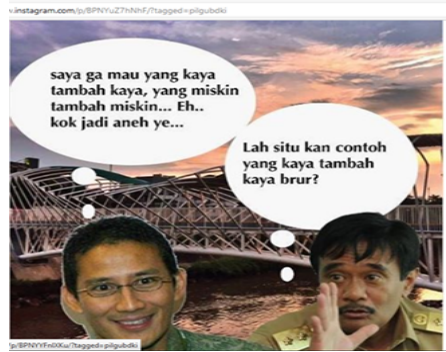

Source: Instagram \#pilgubdki

This meme is deliberately titled 'The Rich is Getting Richer', in accordance with the text highlighted on the meme. This meme is also appeared and posted on \#pilgubdki hashtag on February 13, 2017. The signifier that appears in this meme is Sandiaga Uno, the vice governor candidate who paired with Anis Baswedan, and Djarot Saiful Hidayat, the vice governor candidate who paired with Basuki Tjahaja Purnama, widely known as Ahok. The meme depicts the background of the river with a bridge over it. The photo shows Sandi put a close up image with the focus on his smiling faces while stating, "I do not want the rich get richer while the poor get poorer. Why it sounds so weird?" On the second signifier, Djarot spotted on with the hand near to his mouth and whispered to Sandi, "You are the example of the rich getting richer, Dude!"

In the first signifier, there is an unfinished sentence, such as "Why it sounds so weird? ..." It means that there is a mistake in Sandi's statement. Previously, he mentioned "The rich get richer," Sandi is a notably successful young entrepreneur, his affluence grows from certain businesses he owns. However, his words are the opposite of his reality. It is like he got slapped in his face. This proverb illustrates inconsistency between Sandi's statement and the reality that he is the rich who is getting richer.
This inconsistency is emphasized by the second signifier of Djarot with the phrase, "You are the example of the rich getting richer, Dude!" This sentence is intentionally asserted by the meme creator to question what Sandi has done to alter the poor not getting poorer, nothing has seen or has been exposed. The visible reality which consciously raised is that Sandi is an obvious example of his statement 'the rich are getting richer.'

\section{C. the analysis of meme; "Kapan Digusur?"(= "When you} will be evicted?")

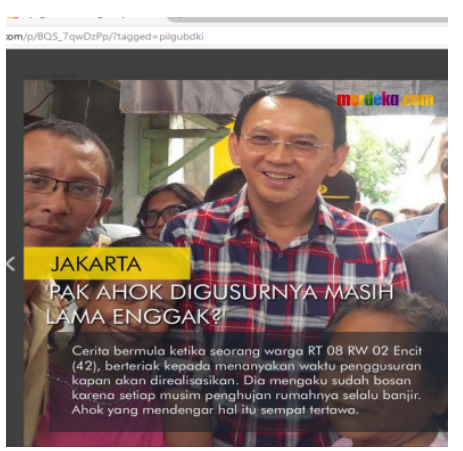

Source: Instagram \#pilgubdki

This meme appeared on \#pilgubdki hashtag on February 14,2017 . This meme is somewhat varied from the majority of other memes. It looks like this meme was made by people who joined www.merdeka.com. This meme is highlighted with the residents and Ahok during the campaign trail. This photo was captioned with a long text and went viral on Instagram. There are several signifiers on this meme, such as; First, Ahok was laughing and surrounded by the residents, is signified the proximity of Ahok with the residents. The second signifier appears on a fairly long article in the middle to the bottom of the meme. The text is quite prominent such as "Ahok, the eviction still takes time?" The text means that Encit, the Jakarta resident mentioned in the text, prefers to be evicted and live in the government flats compared to living in her often-flooded house.

This meme as a whole contains a sign of successful relocation program of the flood-prone housing to the public flats. This program is not perceived as an eviction that harms citizens but instead provides a better replacement house. The success of this program is confirmed by a statement from Encit, the 42 years old resident. This text is intentionally shared with the purpose and implied meaning to block or 'break' the allegations of the eviction which has harmed the evicted residents. In addition, the captioned text intended to create a positive imagery of Ahok and the relocation program.

Based on the analyzed memes which appeared during the political campaign, mainly during the silent periods, it can be deduced that those memes bring "subtle" political image, with the audience unaware of this. A positive imagery built up 
during the debate and the campaign trail subsequently tear down with the Internet meme created by a political opponent. The memes aimed to criticize and to attack the opponents with symbols and words to diminish the positive imagery while, at the same time, escalating the negative imagery. It is best described in "Jakarta Will Get High" and "The Rich is Getting Richer" memes. On the other hand, "When you will be evicted?" memes tend to create a positive imagery towards Basuki Tjahaja Purnama or Ahok.

If we took a glance over the political culture of Jakarta Gubernatorial Election 2017, it is evident that the election and political campaign still contain subtle political imagery. The regulation and ethics of the campaign appear to be violated. For instance, when supporter still generates some political campaign symbols in their memes during the silent periods. It could influence public opinion, shape public views, and left them in doubts over their predetermined choice. In addition, the culture of offending the opponents is evident in some ways, such as attacking the campaign promises, paying attention to the misspoken words, misused languages, language deficiencies (langue), and speech act (parole) both in the diction and interpreted the meaning of the statement.

\section{CONCLUSION}

The well known memes with \#pilgubdki hashtag on Instagram are somewhat distinctive than any other eminent meme before in Indonesia. More prominently, the memes in the silent period are more visible in term of directly attacking the political opponents, especially with the long caption embedded in the picture. It is not only satire but also outspoken. The signs of ethnicity, religious view, racial issues, and the twist of reality are used to attack and demolish the political opponent. The political imagery for the three candidates appears to be more subtle and implicit, but the "attack" from the opponent is more evident, especially in criticizing the weaknesses of the campaign promises, language used, and speech act.

\section{ACKNOWLEDGMENT}

My honorable mention to the Ministry of Research, Technology and Higher Education of Indonesia for supporting this research.

\section{REFERENCES}

[1] L. Shifman, Memes in Digital Culture. The United States of America: The MIT Press Essential Knowledge series, 2014.

[2] R. Dawkins, The Selfish Gene, 30th anniv. New York: Oxford University Press, 2006.
[3] L. Shifman, “journal of visual culture,” vol. 13, no. 3, pp. $340-358,2014$.

[4] C. Mauricio and C. Díaz, "Defining and characterizing the concept of Internet Meme," Rev. CES Psikologia, vol. 6, pp. 82-104, 2013.

[5] L. Shifman, "Memes in a Digital World: Reconciling," J. Comput. Commun., vol. 18, pp. 362377, 2013.

[6] M. Dynel, ““ I Has Seen Image Macros !' Advice Animal Memes as Visual-Verbal Jokes," vol. 10, pp. 660-689, 2016.

[7] J. Wang and H. Wang, "From a Marketplace to a Cultural Space : Online Meme as an Operational Unit of Cultural Transmission," J. Tech. Writ. Commun., vol. 45 , no. 3 , pp. 261-174, 2015.

[8] R. P. Wadipalapa, "Meme Culture \& Komedi- Satire Politik: Kontestasi Pemilihan Presiden dalam Media Baru," J. Ilmu Komun., vol. 2, no. 1, pp. 1-18, 2015.

[9] L. Grundlingh, "Memes as speech acts," Soc. Semiot., vol. 1, no. Memes, pp. 1-23, 2017.

[10] R. . Goodin and C. Tilly, "Contextual Political Analysis," in The Idea of Political Culture, First., R. E. G. And and C. TILLY, Eds. New York: Oxford University Press, 2006, p. 882.

[11] G. A. Almond and S. Verba, The civic culture:political attitudes and democracy in five nations, First. United State of America: SAGE Publications, Inc, 1989.

[12] R. P. Formisano, "The Concept of Political Culture," J. Interdiscip. Hist. xxxi, vol. 3, no. Political Culture, pp. 393-426, 2001.

[13] M. Budiardjo, Dasar-dasar Ilmu Politik. Jakarta: Gramedia Pustaka Utama, 2008.

[14] D. Strinati, Popular Culture Pengantar menuju teori budaya populer, 1st ed. Jakarta: Narasi, 2016.

[15] R. Barthes, Mitologi, 1st ed. Yogyakarta: Kreasi Wacana, 2004. 